\title{
An evaluation of phytochemical screening of Lantana camara Linn. (An invasive plant species of Pakistan)
}

Hira Gul $^{1}$, Zaib-Un-Nisa ${ }^{1 *}$, Aiman Jabeen ${ }^{1}$, Maryam ${ }^{1}$ and Muhammad Anwar Sajad ${ }^{2}$

1. Department of Botany, Women University Swabi, Khyber Pakhtunkhwa-Pakistan

2. Department of Botany, Islamia College (A Public Sector University) Peshawar, Peshawar, Khyber Pakhtunkhwa-

Pakistan

*Corresponding author's email: zaib2864@gmail.com

Citation

Hira Gul, Zaib-Un-Nisa, Aiman Jabeen, Maryam and Muhammad Anwar Sajad. An evaluation of phytochemical screening of Lantana camara Linn. (An invasive plant species of Pakistan). Pure and Applied Biology. Vol. 9, Issue 3, pp1856-1863. http://dx.doi.org/10.19045/bspab.2020.90198

\begin{tabular}{llll}
\hline \hline Received: 17/02/2020 & Revised: 27/04/2020 & Accepted: 08/05/2020 & Online First: 13/05/2020 \\
\hline
\end{tabular}

\section{Abstract}

Lantana camara Linn. is an invasive plant species in Pakistan, but also a very important medicinal plant. Current research was conducted to determine its different metabolites. $\mathrm{FeCl}_{2}$ was used for detection of phenolic compounds and found in different plant parts in higher quantity. For the determination of terpenoids and steriods $\mathrm{CHCl}_{3}$ and $\mathrm{H}_{2} \mathrm{SO}_{4}$ while $\mathrm{NaOH}$ was used to test cumarines and quinones and were found in all plant parts in sufficient amount. Distilled water and $\mathrm{HCl}$ were used to test the presence of phlobatanins but were absent in both ethanolic and methanolic extracts. Oil and fats were absent in all plant parts, no chemical was used in detection of oil and fats. For reducing sugars distilled water and Fehling solution A and B were used which showed that reducing sugar was present only in the ethanolic extract of the leaves. Whereas, only in methanolic extracts of leaves and flowers reducing sugars were found. Saponin was found only in methanolic extract of fruits whereas, the ethanolic extracts of stem and flowers showed the presence of saponins. Overall results indicated that L. camara contain important metabolites i.e. glycosides, saponins, tannins, flavonoids, phenolic compounds, quinones, cumarines, reducing sugars, phlobatanins, terpenoids and steroids due to which should be used for various infectious diseases, and in numerous traditional medicinal preparations. Furthermore, as the plant is an invasive species and cause harder for native plants so can be utilized for its medicinal purposes in large numbers and can be managed.

Keywords: Invasive species; Lantana camara; Phytochemical screening

\section{Introduction}

All the flora are very useful in term of medicines [1, 2] because herbal medicines are used to treat many infectious diseases. These plants possess some important phytochemical compounds such as alkaloids, flavonoids, saponins, phenols occur in the plant root, stem, Leaves, flowers and seeds.
Nowadays natural herbs attain high position due to the presence of many affective reagents which are used for the dermatological infections. Various medicines are produced from secondary metabolites which are used against various disorders [36]. 
L. camara belonging to family Verbinaceae, within the order Lamiales and it includes about 150 species [7]. It was initially presented in Europe in 1636 [8] and was popularly cultivated in the second half of the nineteenth century [9].

Lantana camara is a wild medicinal plant and is distributive from north to South America. This is now spread throughout 60 countries in Mexico, Florida and Brazil. It is an ornamental flowering plant and grows about 1-3 $\mathrm{m}$ in altitude but invasive species of Pakistan. Their leaves are shady green ovate, opposite and are 3-8 cm in length and 3-6 cm wide spread, stem is hairy shrubby, flower is small, tubular in shape and arranged in the form of groups called umbel. Flowers are different in colour it may be red, orange, yellow, white and pink. Usually flowers change its colour due to its maturity. Stamens are four in two pairs, and ovaries are two celled. Inflorescence is dome shaped and about 20-40 sessile flowers. The roots of this plant are very strong and their stem gives out a large number of new shoots after cutting their branches [10].

This plant is used in medicines as well as ornamentally very important. Its leaves exhibit antimicrobial, antifungal and insecticidal activity. They are also very important as ethnomedicines because it is used in various medicines for a lot of disease such as ulcer, catarrhal infection, malaria, tumor, cancer, ulcer, eczema, fevers, cold, chicken pox, asthma, swelling, measles, tetanus and high blood pressure [11]. The vegetative parts of the plant are used for the action of rheumatism [12], for fast-tracking deep respiration, stimulates the intestinal activities etc. also used for carminative and antiseptic properties [13, 14]. The main objectives of the research work were to check the presence or absence of phytochemical constituents in L. camara as it is an invasive species in Pakistan so use in large amount for its medicinal purpose to manage the plant.

\section{Materials and methods For primary metabolites Collection of plant}

For metabolites detection in L. camara, the aerial parts of the plant were collected from Women University, Swabi, Khyber Pakhtunkhwa Pakistan. For primary metabolite detection fresh parts, i.e. stem, leaves, flower and fruit of the plant were used. These parts were collected and separately washed well with tape water then with distilled water to remove all the impurities. These parts were left for a while to drain all the water, weighed and then ground to form a well paste $[14,15]$.

For the analysis of secondary metabolites all the collected plant parts were cleaned then placed on newspaper separately and tagged them. These Ariel parts are then dried in shade. Each part was crushed and grind into well powdered [3-6]. The entire laboratory work was carried out in the Department of Botany, Women University Swabi. The following methods were adopted for metabolites determination:

\section{Lutein}

$10 \mathrm{~g}$ of fresh parts were crushed and dipped in ethanol for some time and then filtered the solution by using filter paper. This filtrate was then poured into the test tubes and centrifuged for 10 minutes at 10,000 rpm. The upper clear white layer was collected with the help of syringes. This supernatant was stored at $4{ }^{\circ} \mathrm{C}$ for 10 minutes then checked the optical density with the help of spectrophotometer at the wavelength of 446 $\mathrm{nm}$, also checked the blank optical density, the blank of lutein is acetone or ethanol [16].

\section{Anthocyanin}

About 0.3 gram of fresh parts was crushed separately. This paste was dipped into the extraction buffer, (for extraction buffer about $45 \%$ methanol and 5\% concentrated acetic acid were mixed and then cooled) about $3 \mathrm{ml}$ of extraction buffer was then poured into each ground part and then centrifuged at 
$12000 \mathrm{rpm}$ for 5 minutes, then collected the supernatant and was poured it into new falcon tubes and again centrifuged for 5 minutes at $12000 \mathrm{rpm}$. The top aqueous layer was collected and checked the optical density about the wavelength is $530 \mathrm{~nm} / 657 \mathrm{~nm}$. Blank of anthocyanin was the extraction buffer [17].

\section{Beta carotein}

For the beta carotein screening, about 95\% ethanol was used; $10 \mathrm{~g}$ sample was taken in 5 $\mathrm{ml}$ of ethanol. Then it was put into water bath for about 20 minutes at $70-80{ }^{\circ} \mathrm{C}$. Then relaxed it for about 5 minutes and collected the supernatant through syringes and was cooled. $15 \mathrm{ml}$ of ethanol was added into the previous ethanol and then cooled for 10 minutes. Taken separating funnel, the supernatant was poured with $5 \mathrm{ml}$ of petroleum ether and $5 \mathrm{ml}$ of cold ethanol and shake for 2 seconds. The dense layer was removed whereas the white upper clear layer was collected and checked the optical density of each sample. Also checked the blank optical density at the wavelength of $436 \mathrm{~nm}$, the blank of beta carotein was petroleum ether [18].

\section{Chlorophyll}

About $0.2 \mathrm{~g}$ of leaves was taken in ethanol at about $80 \%$ and then placed it into the water bath for about 1 hour. The supernatant was collected and checked their optical density at about $645 \mathrm{~nm}$ and $663 \mathrm{~nm}$ [19].

\section{For secondary metabolites}

\section{Extraction}

The dried parts of L. camara were broken into small pieces and ground in a grinder to form well powder. $20 \mathrm{~g}$ of plant materials were socked in $90 \%$ methanol and ethanol for 14 days and shacked it every day to form a good solution. The crude methanol and ethanol extracts were filtered. The solvent was recollected and the concentrated extract was dried through water bath at $55^{\circ} \mathrm{C}[6,20]$.

\section{Phytochemical analysis}

The tests were performed on the Methanolic and ethanolic extracts of $L$. camara using standard procedures to identify the ingredients $[6,20]$.

\section{Oil and fats}

$0.5 \mathrm{ml}$ of the extract was evaporated on a filter paper. The filter paper was then dried and observed for transparency or oily appearance on the filter paper, indicating the presence of fixed oils and fats [16].

\section{Tannins}

A small amount of each extract was mixed with water, heated on a water bath, and then filtered. A few drops of ferric chloride were added to the filtrate. Dark green solution indicates the presence of tannins [21].

\section{Glycosides}

The extract was hydrolyzed with hydrochloric acid (HCL) and neutralized with a sodium hydroxide $(\mathrm{NaOH})$ solution. A few drops of Fehling's solution A and B were added. Red precipitate indicated presence of glycosides [21].

\section{Reducing Sugars}

The extract was tested with distilled water and filtered. The filtrate was boiled with a few drops of Fehling solutions A and B for several minutes. Orange-red precipitation indicates the presence of reducing sugars [21].

\section{Saponins}

Approximately $0.2 \mathrm{~g}$ of the extract was added in $5 \mathrm{ml}$ of distilled water and then heated to boiling. Foaming (small creamy bubbles) was the indication of saponin presence [21].

\section{Flavonoids}

The procedure of Trease and Evans et al. [21] was used for the determination of flavonoids. Extract of about $0.2 \mathrm{~g}$ was dissolved in diluted $\mathrm{NaOH}$ and $\mathrm{HCl}$ was added. If a yellow solution turns colorless, it will indicate the presence of flavonoids.

\section{Phlobatanins}

The extract $(0.5 \mathrm{~g})$ was dissolved in distilled water and filtered. The filtrate was boiled 
with $2 \% \mathrm{HCl}$ solution. Red precipitate showed the presence of Phlobatanins [21].

\section{Terpenoids test}

$0.2 \mathrm{~g}$ of each part of L. camara extract was mixed with $2 \mathrm{ml}$ of chloroform and about 3 $\mathrm{ml}$ concentrated $\mathrm{H}_{2} \mathrm{SO}_{4}$ was carefully added to form a layer [21].

\section{Coumarins}

$2 \mathrm{ml}$ of extract was added with $3 \mathrm{ml}$ of dilute $\mathrm{NaOH}$. Yellow color was the indication of the Coumarins presence [22].

\section{Quinones}

$1 \mathrm{ml}$ of extract of was treated with $2 \mathrm{ml}$ of dilute $\mathrm{NaOH}$. Blue green or red color confirms the presence of Quinones [23].

\section{Phenolic compounds}

A few drops of plant extract were added to $5 \%$ aqueous ferric chloride. Dark blue or black color indicates the presence of the phenolic compounds [24].

\section{Steroids}

$1 \mathrm{ml}$ of extract was dissolved in $10 \mathrm{ml}$ of chloroform; equal volume of concentrated sulphuric acid was added by the sides of the test tube. The upper layer becomes red while lower becomes yellow with green fluorescence indicate the presence of steroids [22].

\section{Results and discussion}

By performing tests of primary metabolites such as lutein, beta-carotene and anthracyanines. Different optical density was observed through spectrophotometer as shown in the (Table 1).

Results were obtained by the phytochemical analysis of secondary metabolites in different parts of L. camara, L. as shown in (Table $2 \&$ 3). About 15 phytochemicals were screened; only ten phytochemicals were detected in various solvent extracts of the plant. Similar results were also reported by Sushama Raj [25]. These extracts were consisting of free amino acids, proteins, carbohydrates, alkaloids, flavonoids, terpenoids, saponins, phenol and vitamin $\mathrm{C}$. The presence of quinones was observed in the plant, but was found in negligible amount in ethanolic extracts of leaf, flower and fruit but in methanolic extracts only leaf having a negligible amount of cumarines. Phlobatanin was not observed in all parts of $L$. camara in ethanolic as well as methanolic extracts including leaves, flower, stem and fruit. Furthermore, glycoside was also not observed in ethanolic and methanolic extracts of stem, flower and fruit. Tiwari et al. [26] showed that those factors which affects the solvent are, the quantity of phytochemicals to be extracted, rate of extraction, diversity of different extracted compounds, diversity of inhibitory compounds extracted, affluence of subsequent handling of extracts, toxicity of solvent in a bioassay process and potential health hazard of extract. The results showed that the alkaloids in different plant parts were present in petroleum ether extracts but these were absent in all other plant parts extracts. Proteins, steroids and carbohydrates were present only in alcohol and chloroform. This corroborates the report of Tiwari et al. [27]. The extracts of L. camara were showed that the presence of tannins, flavonoids, terpenoids, saponins, cumarines, quinones, reducing sugars, phenolic compounds and steroids. These were the major phytochemical groups as shown in (Table 2 \& 3). Different extracts of organic solvents of the plant were showed the presence of triterpenoids, carbohydrates, proteins, flavonoids, resins, tannins and fixed oils. Our results are in agreement with the research work of Verma and Verma [28]. It was observed that the use of ethanol as organic solvent concentrates more water-soluble compounds i.e. saponins and tannins.

Various chemical tests were performed for primary metabolites consist of lutein, beta carotenes, proteins, amino acids and chlorophyll etc. Whereas secondary metabolites consist of tannins, saponins, alkaloids, flavonoids, glycosides, reducing sugars, oil and fats. By performing tests for 
detection of flavonoids in Lantana camara, the ethanolic extracts of fruit and stem showed the presence of flavonoids but methanolic extracts of leaves only showed the presence of flavonoids. In other plant parts it was not observed. Ethanolic extracts of flowers and stem were showed the presence of saponins in minimum quantity as appeared light creamy mass. The presence of saponins in others parts of the Lantana camara of ethanolic and Methanolic extracts were not observed. Ethanolic and Methanolic extract of flowers and leaves were showing the presence of tannins, but in the ethanolic flower extract. It was found in minimum quantity or negligible. While in other plant parts tannin was absent.

Ethanolic extracts of flower and methanolic extract of stems and flowers were showed the presence of terpenoids. Whereas, ethanolic and methanolic extracts of other parts of the plant haven't shown its presence. Oil and fats were not found in any part of the plant. Similar results were also reported by Suffredini et al. [29].

Table 1. Phytochemical analysis of primary metabolites in leaves, flowers, seeds and stem of Lantana camara

\begin{tabular}{|c|c|c|c|c|c|c|c|c|}
\hline $\begin{array}{c}\text { S. } \\
\text { No. }\end{array}$ & $\begin{array}{c}\text { Primary } \\
\text { metabolites }\end{array}$ & Blank & wavelength & Blank OD & Leaf OD & $\begin{array}{c}\text { Stem } \\
\text { OD }\end{array}$ & $\begin{array}{c}\text { Flower } \\
\text { OD }\end{array}$ & $\begin{array}{c}\text { Fruit } \\
\text { OD }\end{array}$ \\
\hline $\mathbf{1}$ & Lutein & Acetone & $446 \mathrm{~nm}$ & 0.000 & 0.157 & 0.231 & 0.256 & 0.521 \\
\hline $\mathbf{2}$ & Beta carotein & $\begin{array}{c}\text { Petroleum } \\
\text { ether }\end{array}$ & $436 \mathrm{~nm}$ & 0.000 & 1.731 & 2.553 & 2.009 & 2.769 \\
\hline $\mathbf{3}$ & Anthocyanins & $\begin{array}{c}\text { Extraction } \\
\text { buffer }\end{array}$ & $\begin{array}{c}530 \mathrm{~nm}- \\
657 \mathrm{~nm}\end{array}$ & 0.000 & 0.153 & 0.247 & 0.173 & 0.261 \\
\hline $\mathbf{4}$ & Chlorophyll & Ethanol & $\begin{array}{c}663 \mathrm{~nm}- \\
645 \mathrm{~nm}\end{array}$ & 0.000 & $\begin{array}{c}1.791- \\
0.780\end{array}$ & - & - & - \\
\hline
\end{tabular}

Table 2. Phytochemical analysis of secondary metabolites in ethanolic extracts of Lantana camara leaves, stem, flower and fruits

\begin{tabular}{|c|c|c|c|c|c|c|c|}
\hline $\begin{array}{c}\text { S. } \\
\text { No }\end{array}$ & $\begin{array}{c}\text { Secondary } \\
\text { metabolites }\end{array}$ & Chemicals used & Detection & Leaves & Stem & Flower & Fruit \\
\hline $\mathbf{1}$ & Tannins & Distilled water & Green colour & + & $+/-$ & - & - \\
\hline $\mathbf{2}$ & Phlobatanins & Distilled water, HCl & Red colour & - & - & - & - \\
\hline $\mathbf{3}$ & Flavonoids & $\mathrm{HCl}, \mathrm{NaOH}$ & $\begin{array}{c}\text { Yellow colour turn } \\
\text { colorless }\end{array}$ & - & + & - & + \\
\hline $\mathbf{4}$ & Glycosides & $\begin{array}{c}\text { HCl, NaOH, Fehling } \\
\text { solution a and b }\end{array}$ & red colour & + & - & - & - \\
\hline $\mathbf{5}$ & Terpenoids & CHCL3, H2SO4 & Reddish brown & $+/-$ & - & + & - \\
\hline $\mathbf{6}$ & $\begin{array}{c}\text { Reducing } \\
\text { sugar }\end{array}$ & $\begin{array}{c}\text { Distilled water, Fehling } \\
\text { solution A and B }\end{array}$ & Orange red & + & - & - & - \\
\hline $\mathbf{7}$ & Saponins & Distilled water & Creamy mass & - & $+/-$ & $+/-$ & - \\
\hline $\mathbf{8}$ & Oil and fats & No chemicals & Oil & - & - & - & - \\
\hline $\mathbf{9}$ & Steroids & $\begin{array}{c}\text { Chloroform and } \\
\text { Sulphuric acid }\end{array}$ & $\begin{array}{c}\text { Upper is red while } \\
\text { lower is yellow } \\
\text { greenish }\end{array}$ & - & - & $+/-$ & + \\
\hline $\mathbf{1 0}$ & Cumarines & NaOH & Yellow colour & + & + & + & + \\
\hline $\mathbf{1 1}$ & $\begin{array}{c}\text { Phenolic } \\
\text { compounds }\end{array}$ & Ferric chloride & $\begin{array}{c}\text { Blackish or dark blue } \\
\text { colour }\end{array}$ & + & + & + & + \\
\hline $\mathbf{1 2}$ & Quinones & NaOH & Reddish colour & $+/-$ & + & $+/-$ & $+/-$ \\
\hline
\end{tabular}


Table 3. Phytochemical analysis of methanolic extracts of Lantana camara leaves, stem, flower and fruit

\begin{tabular}{|c|c|c|c|c|c|c|c|}
\hline $\begin{array}{c}\text { S. } \\
\text { No. }\end{array}$ & $\begin{array}{c}\text { Secondary } \\
\text { metabolites }\end{array}$ & Chemical used & Detection & Leaves & Stem & Flower & Fruit \\
\hline $\mathbf{1}$ & Tannins & Distilled water & Green colour & + & - & $+/-$ & - \\
\hline $\mathbf{2}$ & Phlobatanins & Distilled water and HCl & Red colour & - & - & - & - \\
\hline $\mathbf{3}$ & Flavonoids & HCL, NaOH & $\begin{array}{c}\text { Yellow colour } \\
\text { turn colorless }\end{array}$ & + & - & - & - \\
\hline $\mathbf{4}$ & Glycosides & $\begin{array}{c}\text { HCl, NaOH Fehling } \\
\text { solution A, B }\end{array}$ & red colour & + & - & - & - \\
\hline $\mathbf{5}$ & Terpenoids & CHCl3, H2SO4 & Reddish brown & $+/-$ & + & + & $+/-$ \\
\hline $\mathbf{6}$ & Reducing sugar & $\begin{array}{c}\text { Distilled water, Fehling } \\
\text { solution A, B }\end{array}$ & Orange red & + & - & $+/-$ & - \\
\hline $\mathbf{7}$ & Saponins & Distilled water & Creamy mass & - & - & - & $+/-$ \\
\hline $\mathbf{8}$ & Oil and fats & No chemical & Oil & - & - & - & - \\
\hline $\mathbf{9}$ & Steroids & $\begin{array}{c}\text { Chloroform and } \\
\text { Sulphuric acid }\end{array}$ & $\begin{array}{c}\text { Upper layer is red } \\
\text { lower is yellow }\end{array}$ & + & - & + & + \\
\hline $\mathbf{1 0}$ & Cumarines & NaOH & Yellow colour & + & + & + & + \\
\hline $\mathbf{1 1}$ & Phenolic & Ferric chlorides & $\begin{array}{c}\text { Blackish or blue } \\
\text { colour }\end{array}$ & + & + & ++ & - \\
\hline $\mathbf{1 2}$ & Quinones & NaOH & Reddish colour & $+/-$ & + & + & + \\
\hline
\end{tabular}

The test of reducing sugar indicated its presence in leaves ethanolic and methanolic extracts. Furthermore, it was also observed in the methanolic extract of flowers. The presence of cumarine was found in all parts of $L$. camara in both ethanolic and methanolic extracts. The ethanolic stem and methanolic flowers and stem were showed the presence of Quinones, other parts were showed its negligible quantity [27].

All parts of Lantana camara in ethanolic and methanolic extracts were showed the presence of phenolic compounds, but the methanolic extract of fruit was not showing its presence. While steroids were present in ethanolic and methanolic extracts of fruit. Methanol leaf and flower extracts were also showed the presence of steroids whereas ethanolic extracts of flowers were indicated negligible amount of these compounds. Glycosides and phlobatanins were not observed in any part of L. camara in both ethanolic and methanolic extracts. These results are in aggrement of Suffredini et al. [30].

\section{Conclusion}

Lantana camara is a major invasive species of Pakistan. It is concluded from current research work that all parts of the plant contain various phytochemicals i.e primary metabolites as well as secondary metabolites. primary metabolites include various compounds such as lutein, Beta carotein and anthocyanin, whereas secondary metabolites consists of glycosides, saponin, tannins, flavonoids, cumarines, quinones, phenolic compounds, steroids, Phlobatanins, reducing sugars, oil and fats and terpenoids. These compounds are used for various infectious diseases and also used as ethnomedicines. By this study, it was confirmed that the selected plant species is a potent source of useful drugs.

\section{Authors' contributions}

Conceived and designed the experiments: $\mathrm{ZU}$ Nisa \& H Gul, Performed the experiments: $\mathrm{H}$ Gul, Analyzed the data: ZU Nisa \& H Gul, Contributed materials/ analysis/ tools: A Jabeen, Maryam \& MA Sajad, Wrote the paper: ZU Nisa \& H Gul. 


\section{Acknowledgment}

The research was conducted in the laboratory Department of of Botany, Women University, Swabi, Khyber Pakhtunkhwa.

\section{References}

1. Nisa ZU, Jan S \& Shah SH (2016). Standardization of Protocol for the Surface Sterilization and Callus Induction of Saussurea lappa: An Endangered Medicinal plant. IJB 9(1): 324-330.

2. Javanmardi J, Stushnoff C, Locke E \& Vivanco JM (2003). Antioxidant activity and total phenolic content of Iranian Ocimum accessions. $J$ Food Chem 83: 547-550.

3. Nisa ZU, Jan S, Sajad MA, Shah SH, Farooq G \& Ali H (2018). Micropropagation through apical shoot explants and morphogenic potential of different explants of Saussurea lappa: An endangered medicinal plant. Pure Appl Biol 8 (1):585-592.

4. Nisa ZU, Shah SH, Farooq G, Sajad MA, \& Khan MAS (2019). Identification, quantification and comparative assessment of costunolide in wild, cultivated and in vitro callus culture of Saussurea lappa by HPLC technique. Pure Appl Biol 8(1): 910-919.

5. Nisa ZU, Shah SH, Farooq G, Sajad MA $\&$ Khan MAS (2019). Distribution and comparison of major selected elements in root of wild plant, root derived calli and various anatomical parts of cultivated Saussurea lappa: An endangered medicinal plant. Pure Appl Biol 8(2): 1478-1486.

6. Nisa ZU, Jan S, Shah SH, Farooq G, Sajad MA \& Khan MAS (2019). Assessment of the callus induction, relative growth rate, proline and sugar in Saussrea lappa C.B. Clarke. Pure Appl Biol 8(1): 838-846.

7. Gujral GS \& Vasudevan P (1983). Lantana camara L., a problem weed. $J$
Sci \& Indus Res 42: 281-286.

8. Stirton CH (1977). Some thoughts on the polyploidy complex Lantana camara L. (Verbenaceae). In Proceedings of the Second National Weeds Conference of South Africa, ed. D. P. Annecke, Cape Town, South Africa: AA Balkema, pp 321-340.

9. Swarbrick JT, Willson BW \& HannanJones MA (1998). Lantana camara L. In the Biology of Australian Weeds, ed. FD Panetta, RH Groves and RCH Shepherd. Melbourne, Australia: $R G$ and FJ Richardson pp 119-140.

10. Sastri BN (1962). The wealth of India. CSIR New Delhi, India.

11. Kalita S, Kumar G, Logonathan K, Venkata K \& Rao B (2012). Review of medicinal properties of Lantana camara Linn. Research J pharma and technol 5(6): 711-715.

12. Chowdhury JU, Nandi NC \& Bhuiyan NI (2007). Chemical composition of leaf essential oil of Lantana camara L. Bangl J of Bot 36: 193-194.

13. Noble D, Lane SJ, Sidebottom PJ \& Lynn SM (1998). Isolation of translactonecontaining triterpenes with thrombin inhibitory activities from the leaves of Lantana camara. J Nat Pro 61(11): 1328-1331

14. Nagao $\mathrm{T}$, Abe $\mathrm{F}$, Kinjo $\mathrm{J}$ \& Okabe $\mathrm{H}$ (2002). Antiproliferative constituents in plants 10. Flavones from the leaves of Lantana montevidensis BRIQ and consideration of structure activity relationship. Biol and Pharma Bull 25: 875-879.

15. Sajad MA, Khan MS, Ali H \& Nisa ZU (2018). Lead phytoremediation potential of sixty-one plant species: An open field survey. Pure Appl Biol 8(1): 405-419.

16. Sajad MA, Khan MS, Ali H, NisaZU \& Khan MAS (2019). Evaluation of nickel phytoremediation potential of Rumex dentatus: a greenhouse experiment. Pure 
Appl Biol 8(2): 1062-1068.

17. Panfili G, Frtianni A \& Irano M (2004). Improved normal phase performance liquid chromatography procedure for the determination of carotenoids in cereals. $J$ Agric Food Chem 52: 63-73.

18. Nile SH, Kim DH \& Keum YS (2015). Determination of anthocyanin content and antioxidant capacity of different grape varieties. Ciência Téc Vitiv 30(2): 60-68.

19. Ahamad MN, Saleemullah M, Shah HU, Iqtidar A, Khalil and Saljoqi AUR (2007). Determination of beta carotene content in fresh vegetables using high performance liquid chromatography. Sarhad J Agric 23(3).

20. Gogoi M \& Basumatary M (2018). Estimation of the chlorophyll concentration in seven Citrus species of Kokrajhar district, BTAD, Assam, India. Tropical Plant Res 5(1): 83-87.

21. Savithramma N, Linga Rao M \& Suhrulatha D (2011). Screening for medicinal plants for secondary metabolites. Middle East J Sci Res 8(3): 579-584.

22. Malik S, Khan MS, Sajad MA, Barkatullah, Saddiq G, Nisa ZU, Shah M and Aziz N (2019). Evaluation of antibacterial potential of the leaves, flowers and bulbs of Allium neapolitanum cirillo Pure Appl Biol 8(3): 2076-2086.

23. Trease GE \& Evans WC (1989). Pharmacognosy. 13th (ed). ELBS/Bailliere Tindall, London. Pp.
345-6, 535-6, 772-3.

24. Savithramma N, Linga Rao M \& Suhrulatha D (2011). Screening for medicinal plants for secondary metabolites. Middle East J Sci Res 8(3): 579-584.

25. Soni A \& Sosa S (2013). Phytochemical analysis and free radical Scavenging potential of Herbal and Medical plants Extracts. J pharma Phytochem 2(4): 2229.

26. Shah P, Modi HA, Shukla MD \& Lahiri SK (2014). Preliminary phytochemical analysis and Antibacterial activity of Ganodema lucidum collected from Dang District of Gujarat. India. Int $J$ curr Microbiol App Sci 3(3): 246-255.

27. Sushama Raj RV (2017). Preliminary phytochemical screening of Lantana camara L., a major invasive species of Kerala, using different solvents. Middle East J Sci Res 6(11): 1794-1798.

28. Tiwari P, Kumar B, Kaur M, Kaur G \& Kaur H (2011). Phytochemical screening and extraction: A Review. Int Pharma Sci 1(1).

29. Verma RK \& Verma SK (2006). Phytochemical and termiticidal studies of lantana camara varaculeata leaves. Fitoterapia 77: 466-468.

30. Suffredini IB, Sader HS, Goncalves AG, Reis AO, Gales AC, Varella AD \& Younes R.N (2004). Screening of antibacterial extracts from plants native to the Brazilian Amazon Rain Forest and Atlantic Forest. Brazilian J Med and Biol Res 37: 279-384. 